DOI: 10.20472/TEC.2017.004.002

JOSEF DE BEER

North-West University, South Africa

\title{
THE ZONE OF PROXIMAL TEACHER DEVELOPMENT UNDER THE MICROSCOPE: REFLECTIONS OF A TEACHER EDUCATOR
}

\begin{abstract}
:
This paper sheds light on the personal practices, experiences and research of a teacher educator, and asks the question whether a teacher educator's inquiries might lead to a better understanding of the complexities of teaching and learning- both for the teacher educator and his/ her student teachers. The author, who has been a teacher educator for the past 25 years, reflect on his own research in pre-service teacher education, and what he and his students have learned from the joint interventions they engaged in. The three interventions reflected upon in this paper, were conceptualized to provide possible solutions to three of the perennial issues that plague teacher education, namely (a) the problem of the apprenticeship of observation; (b) the problem of enactment; and (c) the problem of complexity. Although the research is contextualized in South Africa, literature shows that these are issues of international concern. Using a qualitative research design, the author explores realistic examples of learning from practice for practice, and learning in practice, that he has implemented and researched, as possible solutions to these problems. The findings of three qualitative research studies are examined, and its affordances to enhance the professional development of student teachers is discussed. The theoretical framework is scaffolding student teachers' professional development across the zone of proximal teacher developmentWarford's take on the well-known Vygotskyan concept. The first set of research data deals with case-based teaching in pre-service teacher education. Case-based teaching provokes engaged learning, and provides student teachers with a better understanding of the complexities of the teaching profession. The second set of research data explores the affordances of a technique called prolepsis. Prolepsis refers to an approach where a teacher educator structures a learning opportunity in a way that assumes that the student teachers know more than they actually do. In this case, undergraduate student teachers were expected to teach biology to school learners on Saturdays for an entire year, and to take responsibility for meeting all the requirements set by the Department of Education. The third set of research data refers to a first year excursion for student teachers that the author initialized, and insights that emerged over 10 years of presenting the excursion curriculum. During the four-day excursion, student teachers engage in learning tasks as Homo ludens (the playing human). In this paper the excursion is viewed from a neo-Vygotskian perspective of activity theory.
\end{abstract}

\section{Keywords:}

Pre-service teacher education; engaging pedagogies; case-based teaching; prolepsis; zone of proximal teacher development; excursions; teacher professional development.

JEL Classification: 129,121 


\section{Introduction: the perennial issues that plague teacher education}

South Africa languish at the bottom of the list when it comes to the performance of school learners in science and mathematics (De Beer, 2016). The Centre for Development and Enterprise (2011) makes it clear that teachers are at the centre of South Africa's struggling school system and poor performance of learners. In the CDE report (2011:11) it is stated that “...many South African teachers fall short of national and international norms and standards in respect of subject knowledge, teaching methods and productivity". For this reason both pre-service and in-service teacher development are of prime importance. The author, who has been involved in teacher education for 25 years, focuses on three research studies on innovative approaches in pre-service teacher education that he and his student teachers collectively engaged in. The motto that drove this research could best be described by the words of John Slaughter, as quoted in Chmielewski and Stapleton (2009:53): "research is to teaching what sin is to confession; if you don't participate in the former you have very little to say in the latter". The research findings that emerged, prompted the teacher educator to rethink his own teaching, and to make changes to curricula and pedagogies alike.

Teacher education institutions should be introspective on whether their programmes optimally prepare student teachers for the complexity of the teaching profession. A recurrent theme in the literature is claims of a 'theory-practice divide' (Kinsella and Pitman, 2012; Darling-Hammond, 2006:306; Intrator \& Kunzman, 2009). Kessels and Korthagen (1996:2) refer to the 'gap between our words and the students' experiences that we cannot bridge'. There are several reasons that are listed for this 'gap' or lack of 'practical wisdom' to integrate theory and practice. One of the reasons often cited is what Lortie (1975) refers to as the 'apprenticeship of observation'. Student teachers enter their pre-service teacher education with baggage collected over a 12 year period as school learners. Student teachers often have a naïve understanding of the complexity of teaching, and their naïve ideas and assumptions often stem from observing less than brilliant teachers that they might have had in school. Due to their supposed familiarity with a teacher's work, they often tend to oversimplify the nature of teaching (Gravett et al, 2016). This results in the unfortunate situation that student teachers often view conceptual knowledge in teacher education programs as irrelevant in preparing them for the teaching profession (Korthagen, 2011). Warford (2011:254) therefore warns that teacher educators should first "carefully calibrate student teachers' pedagogical dispositions" in order to better contextualize the (new) conceptual knowledge.

A second reason for the 'theory-practice divide' is the problem of enactment. DarlingHammond (2006:305) states that learning to teach requires student teachers not only to "think like a teacher", but also to "act as a teacher". In South Africa student teachers engage for extensive periods of time in work-integrated learning (WIL), and teacher educators trust that student teachers will learn "to act as teachers" during the WIL experience. The problem however is that student teachers often do not have good mentors during their WIL, and often this lofty ideal of learning to "act as a teacher" 
does not materialize sufficiently. Not only does this necessitates that there are closer links between schools and universities, but it also points to the responsibility that the teacher educator carries in scaffolding the student teacher's learning in order to "act like a teacher".

The third problem leading to the so-called theory-practice divide, is that of the complexity of the teaching profession. Shulman (2004:504) described classroom teaching as "perhaps the most complex, most challenging, and most demanding and frightening activity our species has ever invented". Unfortunately many student teachers enter their pre-service teacher education with a naïve understanding of this complexity, and an inflated confidence in their own abilities (Gravett et al, 2016). The question that could be asked about pre-service teacher education, is whether the sector adequately highlights the complexity of teaching, and whether it promotes problem-based learning through innovative pedagogies among its students.

\section{The three research studies and research methodology}

Feiman-Nemser and Floden (1986) drew particular attention to the issue of "self" when they outlined the shift in research focus from studying teaching at a distance to trying to understand how teachers actually viewed their own work. This shift in focus is important, because the knowledge of teachers is a crucial source of insight for the improvement of teaching. Kosnik et al., (2005:ix) are of the opinion that the same applies to teacher educators: "Thus, it can be argued that through focusing on personal practice and experience, teacher educators' inquiries might lead to a better understanding of the complexities of teaching and learning- for themselves and their students". This paper reflects on the findings of three research studies ${ }^{1}$ that the author conducted, in collaboration with his student teachers.

\section{The affordances of case-based teaching}

The first study relates to the use of cases in teacher education. The research question that guided this qualitative inquiry was: What are the affordances of case-based teaching for the professional learning of student teachers? Data was collected through two focus group interviews with twenty student teachers (10 student teachers per group), and individual interviews with two (other) teacher educators. In addition to this, 100 reflective essays of student teachers were analyzed (from the class of 600 students). In these reflective essays the student teachers were required to reflect on the dilemmas highlighted in the cases, and its implications for their own professional development.

\footnotetext{
${ }^{1}$ The author acknowledges co-researchers in the projects: Sarah Gravett, Nadine Petersen and Helen DunbarKrige.
} 


\section{Prolepsis and scaffolding student teachers' learning across the zone of proximal teacher development: the biology project}

The second study captured the affordances of an innovative intervention whereby student teachers were given the opportunity to teach life sciences (biology) to school learners from a top-performing school that did not offer biology as a subject. This intervention was characterized by the use of a technique known as prolepsis, which "assumes that students know more than they actually do" (Van Lier, 2004:153). For an entire academic year, the student teachers taught the school children biology on Saturdays, under mentorship of the teacher educator. The student teachers had to take full responsibility for all aspects of teaching: adhering to the timeframes ("pace setters") of the Department of Education, developing inquiry learning opportunities (we emphasized a pedagogy of play: learners learning science as Homo ludens (the playing human) (Huizinga, 1955), taking responsibility to ensure that an inclusive approach is followed, and meeting all the requirements of the national curriculum in terms of assessment.

The research question that guided this inquiry was: How do student teachers view their own professional development during this intervention? Data were collected over a two year period $(n=81)$, through individual interviews, focus group interviews, reflective essays of student teachers, and classroom observation. For the latter the Reformed Teaching Observation Protocol (RTOP) instrument was used (Sawada, Piburn \& Judson, 2002).

\section{Learning as Homo ludens about the complexity of teaching during an excursion}

For the past 10 years undergraduate student teachers at two South African universities $^{2}$ engage annually in a four-day excursion. The excursion programme is built around simulation games as a tool to teach social awareness in issues of racism, poverty, HIV/AIDS education and gender, and during the programme the student teachers' social and pedagogical boundaries are expanded (Engeström, 1987). Simulation games can make complex and challenging historical or contemporary processes actable or livable (erlebbar), thus invoking human experience within the rule-bound game (Sitte \& Wohlschlagal, 2001; De Beer \& Henning, 2011). When the student teachers board the buses on campus to go to a nature reserve where the excursion programme is presented, they enter a different activity system. To view this excursion system from a specific perspective ${ }^{3}$, we use an activity theory (Engeström, 1987) lens, which situates the excursion in a specific community and as an "activity

\footnotetext{
${ }^{2}$ Where the author worked: University of Johannesburg, and North-West University.

${ }^{3}$ Refer to: De Beer, J. and Henning, E., 2011. Retreating to a Vygotskian stage where pre-service teachers play out social "dramatical collisions". Acta Academica, 43(4), pp.1 - 24; and De Beer, J., Petersen, N. and DunbarKrige, H., 2012. An exploration of the value of an educational excursion for pre-service teachers. Journal of Curriculum Studies, 44(1), pp.89 - 110. There are also two short videos that can be viewed: https://www.youtube.com/watch?v=zxKWGmJEXrM https://www.youtube.com/watch?v=kj2u-BQqDEU
} 
system" with specific tools (such as the simulation games), rules of conduct (a more informal setting compared to the more formal classroom on campus), division of labour, and a shared object of activity (e.g. developing a more nuanced understanding of the teaching profession) (De Beer \& Henning, 2011). A generic qualitative research design was used, and data related to student experiences and learning were collected over a ten year period $(n=6500)$. Data were collected via questionnaires, educational artifacts (e.g. student teachers portfolios) and interviews.

\section{The theoretical framework: scaffolding student teacher learning across the zone of proximal teacher development}

The view taken in this paper on student teacher learning and professional development is underpinned by Vygotsky's (1978) zone of proximal development. Warford (2011) has refined this Vygotskyan concept in relation to teacher development, and he talks of the zone of proximal teacher development (ZPTD). According to Warford (2011:253) situating learning within a Vygotskyan context blends the academic discourse of the university classroom, with the experiential discourse of the school classroom. Warford states that the ZPTD represents the distance between what student teachers can do on their own without assistance, and the proximal level they might attain through structured mediated assistance (scaffolding) from more capable others (which could be the teacher educator, but also other student teachers). What is important of Warford's construct, is the four stages in which learning and professional development takes place:

Stage 1: Student teachers are required to reflect on prior experiences and assumptions.

Stage 2: During the expert-other stage, scaffolding or mediation will assist the student teacher in her professional development

Stage 3: Internalization: Through critical reflection and journaling, the student teachers start to develop an own footing and voice, and they slowly develop a more nuanced teaching philosophy.

Stage 4: The recursion or de-automatization phase: This is the 'theory to practice' stage, as student teachers confront the dichotomy of theory and practice in all its intensity (Warford, 2011:255).

In all three interventions described in this paper, these stages were followed. Whatever the context of the learning activity is, it is of the utmost importance for student teachers to first share their own (albeit naïve) perceptions and views. The teacher educator can then scaffold learning, by providing theoretical lenses that could be used to interrogate practice. Student teacher reflection is of the utmost importance, 
and the learning that first happens on a social level, needs to be internalized. Lastly, student teachers need to understand how theoretical lenses could be used to crossexamine those "messy" issues in practice.

\section{Data analysis}

In all three research projects, data was analyzed by using Saldana's (2009) coding system: codes were identified, categories were formed, and eventually a number of emerging themes were identified.

\section{Case-based teaching in pre-service teacher education}

Shulman (2004:474) defines a case as "an account of an experience in which our intentions have been unexpectedly obstructed, and the surprising event has triggered the need to examine alternative courses of action". His wife again views a case as "a way to bridge the abstract nature of principles and teaching standards to classroom practice" (Shulman, 2002:2). She continues that "they tell vivid, often moving stories, and give life to abstract principles, and are more likely to be remembered". Merseth (1996:725) alerts to the fact that case-based teaching allows teacher educators to explore "the complex and messy problems of practice". Literature indicates that casebased teaching fosters critical thinking, increase practical knowledge through reflection, and provide a link between educational theories and practice (Gravett et al, 2016). Case-based teaching was used in this context in a first-year class with 600 students. Student teachers were asked to read the case prior to coming to class. The class started with providing the student teachers the opportunity to discuss the case in small groups ( $3-4$ students). (This links with stage 1 in Warford's model). Next, feedback was elicited from some of the groups, which the teacher educator summarized. The student teachers' feedback was then used as a springboard to introduce literature and theory (Warford's stage 2). Student teachers then discussed the case again, but this time they had to use theoretical lenses to interrogate practice. After the class, student teachers had to write personal reflections, on what this case meant for their own professional development (Warford stage 3).

Five major findings emerged from this research. These five themes will be briefly discussed ${ }^{4}$.

\section{Case-based teaching prompts engaged learning}

Student-teachers indicated that they found the case-based teaching enjoyable, and this led to them being more focused than they would normally be in class. In her

\footnotetext{
${ }^{4}$ For a more detailed discussion of the research findings, refer to: Gravett, S., De Beer, J., Odendaal-Kroon, R. and Merseth, K., 2016. The affordances of case-based teaching for the professional learning of student teachers. Journal of Curriculum Studies, DOI: 10.1080/00220272.2016.1149224.
} 
reflection on cases, one student teacher said: "It is so refreshing to hear so many different opinions in class, and not just the views of the lecturer. Although I often do not agree with some of the sentiments of other students, it does make you think".

\section{Case-based teaching enables student-teachers to experience the reality of school teaching vicariously}

The students teachers involved in this study experienced case-based teaching as a valuable pedagogy. It made them experience the reality of school teaching vicariously. The data showed that student teachers experienced the authentic cases as powerful. Some of the comments from student teachers were that cases "puts us in the workplace while (being) in the lecture hall...", "we learn from mistakes even before we get a chance to make them", and "cases are valuable because we get to feel what it's like in practice".

\section{Case-based teaching helps develop an appreciation of the complex nature of teaching}

The data clearly shows that case-based teaching provided student teachers with a more nuanced understanding of what it means to be a teacher. One of the student teachers wrote in his reflection "...you understand the complexity of the teaching profession and you find out there's a lot more behind the door that you don't see as a learner".

\section{Case-based teaching enables student teachers to relate course literature and theory to dilemmas of practice}

In the focus group interviews it was mentioned that using cases in conjunction with the prescribed textbook assisted student teachers to see the relevance of course literature for teaching practice. One of the student teachers commented that "( $w)$ hen we did the case, 'But Ma'am, can't we do it our way first ${ }^{5}$ ?', the reason for studying behaviorism, Piaget, Vygotsky and Gardner suddenly made sense to me. When we did the theory, I was wondering how it is going to help me as a teacher. However, when we looked at the dilemma of Ms. Mendez, it suddenly all made sense to me".

\section{Case-based teaching powerfully elicits student teachers' existing conceptions of teaching}

During the interviews with the teacher educators it became clear that they experience case-based teaching as an effective window into the conceptions that student teachers hold of teaching, and of what it means to be a teacher. The following excerpt

${ }^{5}$ Case taken up in: Gravett, S., Merseth, K.K. and De Beer, J., 2013. Being a teacher: A book of cases. Pearson. 
from an interview with a teacher educator highlights this theme: "...the cases are very powerful to elicit the current conceptions of the students. Let me give you an example. One of the cases that we did with them was a case of this teacher who had a code of conduct in class, and one day lost it with a learner, stormed out of the classroom, etc. Now my sense was, she was a very good teacher because discipline in the class was very positive. The fact that she lost it once is human. But it was very enlightening then to hear students' perceptions, and you could clearly hear it came from their school experience. Some of them were quite amazed when another student suggested the teacher should go back to the classroom and apologize and say 'I have done wrong; I shouldn't have lost my temper. Let's re-negotiate the class rules'. They thought a teacher should never do this. They haven't had this experience that a teacher would ever be willing to apologize to the learners, so that gives very good insight in where they come from..."

This research showed that case-based teaching creates authentic learning experiences that provide what Schön (1987) calls 'a low-risk setting for novice learning'.

\section{'Bungee-jumping' across the zone of proximal teacher development}

The second research study focused on an intervention where student teachers in the final year of their pre-service teacher education worked in small groups of four (thus elements of Japanese lesson study) in teaching biology to school learners on Saturdays. The difference between this intervention and work-integrated learning, is that the student teachers took responsibility for the school children for an entire year, and they were the teachers who had to (under the guidance of the teacher educator) follow the guidelines in the national curriculum, ensure that pedagogies lead to true inclusive education, and plan and execute assessment tasks. It also provided the opportunity of an "ideal island situation", as we were not influenced by the normal (sometimes disruptive!) factors and dynamics in a school. For instance, student teachers had access to any materials and equipment they needed for inquiry learning classes, as they could use university resources.

\section{Four main themes emerged from this study:}

\section{The intervention assisted student teachers in their pedagogical content knowledge (PCK) development}

When the project started at the beginning of the academic year, the student teachers' lessons were generally characterized by transmission-mode pedagogies. Working through numerous PowerPoint slides, with hardly any learner engagement, was the trademark of the first cycle of lessons presented by the student teachers. After such "chalk and talk" lessons, the student teachers generally expressed their satisfaction with the lessons. Another interesting observation, was that the student teachers in the 
beginning were not sensitive towards contextual factors. During a lesson on biotechnology, where traditional healing practices was discussed, one of the student teachers spoke about African traditional healing, and sangomas (an African medicine man, which also engages in metaphysical activities, like making contact with the ancestors). He did not take into consideration that a large percentage of the learners were mostly from Indian descent and Muslim, hence their contextual settings differ from his own. He should have rather asked them about their cultural traditional medicine (e.g. Ayurveda).

Gradually, as the academic year progressed, the "chalk and talk" lessons were replaced by lessons characterized by open-ended inquiries. Student teachers were also more sensitive towards learner diversity, and they prioritized contextual considerations in their lesson planning and presentation.

\section{The intervention provided student teachers with a more nuanced understanding of the nature of science}

One of the student teachers reflected: "What l've realized with school experience, is that teachers don't do practical work at all, and if they do it is always sort of 'cookbook' activities that serve to confirm. In this project we were taught something that we don't learn during school experience- how to facilitate good inquiry labs". Another student reflected: "I could see how the class became alive when we did inquiry activities. I realized that I have to provide learning opportunities in my class one day, that will give my learners a good sense of how a scientist operates. Something of the excitement and messiness of science should be captured in my classroom".

\section{The mentoring from both peers and teacher educators were seen as assisting student teachers in their professional development}

Several student teachers commented on the better mentoring that they experienced in the project, compared to the support by mentor teachers in schools, during school experience: "Most of the time the mentors at the school where we are teaching don't give support to the student teachers. You just ask them what you are going to teach and they tell you and that's it. You have to see for yourself how you are going to deal with the activities. You just teach and when the time comes to leave the school they would ask where did you end. You show them what you did and that's it. They just don't care about their kids and student teachers. There is no support at all". Slowly, through the course of the year, the views of the student teachers of the teacher educators (mentors) being present in the class during the project, change from seeing their role as judgmental and finding fault (initially), to providing mentoring and support. (In the project, every lesson was followed by a reflection session, with all four student teachers and the teacher educator present). The following comment from a student teacher serves as illustration: "I was terrified by the presence of Prof in class on the 
first day. Now I feel most comfortable, because I know he is going to provide supportive feedback that will help me to grow".

The project enhanced affective inclinations like taking responsibility for the learners and adopting a pedagogy of care

Unlike the situation with school experience, where student teachers engage with learners for a few weeks, the student teachers in this project engaged with school learners for an entire year, and developed a sense of responsibility for the learners. Student teachers experienced a feeling of pride and accomplishment, as can be seen from the following quote: "By teaching these learners I feel such a sense of accomplishment. I felt that I was making a contribution that was worthwhile. I cannot wait to see them graduate".

\section{Learning as Homo ludens about the complexity of teaching during an excursion}

When student teachers engage in the excursion activities, they do border-crossing, and put themselves in the shoes of a teacher (as opposed to the formal classroom as a different activity system, where the student teacher thinks and acts more like a student). The following four themes emerged from this longitudinal study over a period of ten years.

\section{The excursion provides a unique space for personal and professional development}

In most lecture rooms, the teacher educator is seen as 'the professor', 'the expert', and 'the assessor'. During the excursion, with its more informal relationships, this intimidating office-bearer, who happily accompanies students on the hikes in the park, becomes a mentor and inspiring role model. For many student teachers who may not have had good teacher role models in schools, the teacher educators become positive role models of the teaching profession (De Beer, Petersen and Dunbar-Krige, 2012).

Very often, the undergraduate student teacher's academic focus can best be described as 'surviving in the academic jungle' - passing tests and submitting assignments on time. During the excursion the student teachers face a different challenge: they have to find their own educational voice(s); during the excursion student teachers are expected to express their individual educational philosophies. The student teacher figuratively has to put on a different hat- that of a teacher (instead of being a student) - therefore addressing the issue of enacting referred to earlier. 


\section{The excursion results in a change in the nature of student teacher- teacher educator relationships, and provide the teacher educator with a better understanding of student teachers' (and his own!) views and biases}

Another theme that emerged from the data, is that teacher educators developed a better understanding of the student teachers and their naïve ideas about teaching that they often bring with them. The data reveals how teacher educators' first impressions of the student teachers are challenged, through their interactions in a more informal setting. The following is an example from a teacher educator's reflections ${ }^{6}$ on this aspect:

"The first day of the excursion is always really frenzied as all equipment and consumables need to be loaded onto the buses. When a young male student with earrings and numerous body piercings volunteered his assistance I immediately thought: this young man is going to give me problems; I need to keep an eye on him! A real gangster! Later that evening, while the rest of the students were enjoying social time, I found this young man, alone in the dormitory working in his reflective journal. In my conversation with him, I realized that the student is in fact an extremely bright young man who had started his university career in engineering and had his bursary withdrawn when he failed a module. His part-time work as a mathematics tutor thereafter convinced him to consider education as a career instead. As a teacher educator I realized that we so often have pre-conceived ideas about students, based on their appearance and mannerisms and that we too need occurrences that prompt us to address our own biases and stereotypes about students".

\section{The excursion assists student teachers to develop sensitivity for cultural diversity}

South Africa is a relatively young democracy, and it would be naïve to think that the wounds left by an apartheid regime, where black peoples' rights were marginalized, would be healed after only 22 years (since 1994). One of the outcomes of the excursion is to sensitize the student teachers towards cultural diversity. Although this is theoretically addressed in the formal classroom, the excursion provides the opportunity to experience this aspect of the student teachers' personal and professional development practically. The following vignette (De Beer, Petersen \& Dunbar-Krige, 2012) is a chilling reminder that social change in a young democracy does not happen overnight:

"While hiking in the park students are allowed to swim in a very deep cave pool. In one of the groups Thandi (a pseudonym), a black female student, swam across the pool

\footnotetext{
${ }^{6}$ From: de Beer, J., Petersen, N. and Dunbar-Krige, H., 2012. An exploration of the value of an educational excursion for preservice teachers. Journal of Curriculum Studies, 44(1), pp.89 - 110.
} 
but lost her nerve and could not swim back. She was assisted by an Afrikaans white female student Elmarie (pseudonym), and the interaction was captured by another student on her cell phone. Elmarie was very angry at this and insisted that all copies of the incident be deleted. Later when reflecting on and discussing the incident, Elmarie indicated that her response was prompted by fear of her father's reaction to her going to the rescue of a black woman. Her reflections indicate her confusion about her own racialized self and identity and how this may impact her work as a teacher in a multiracial and multi-lingual context".

\section{The excursion assist students in envisaging a professional trajectory}

The data shows that the excursion also assists student teachers to envisage a professional trajectory for themselves as teachers.

\section{Discussion and conclusion}

In pre-service teacher education it is of essence to create what Schön (1987) calls 'a low-risk setting for novice learning'. Teacher educators should not assume that workintegrated learning will necessarily provide student teachers with an opportunity to grasp how theory could be used to interrogate practice. The teacher educator should explore opportunities for student teachers to learn in practice and from practice. In the interventions described in this paper, student teachers were challenged- their social and pedagogical boundaries were stretched, or "expanded", in the way that Engeström (1987) uses the term. He describes "expanded learning" as transformation, due to tension that necessitates the stretching of one's understanding, like an elastic band expands when pulled from two sides (De Beer \& Henning, 2011). Two of the described interventions- the excursion and the biology teaching project- especially challenged the student teachers to examine their own 'voice and footing' as teachers. These interventions addressed the perennial problems that were referred to earlier in this paper, namely the apprenticeship of observation, enactment, and the complexity of the profession.

Student teachers who taught biology to school learners for a year (at the university) described their experiences of this prolepsis through metaphors such as the following: "This was an experience ${ }^{7}$ equivalent to "bungee jumping" as everything gets heightened, this includes one fear and stress, but also your joy and satisfaction"; and "Day 1 felt to me like the sinking Titanic. I was so nervous... and every time a learner asked a question, I could feel my heart racing in my chest...". However, the student teachers could also take comfort from the fact that help was always readily available from the teacher educator (as dedicated mentor). Throughout the course of the academic year the student teachers realized that the teacher educator is primarily a

\footnotetext{
${ }^{7}$ Referring to teaching biology to school learners on Saturdays.
} 
mentor (rather than an assessor). The metaphors like 'bungee jumping' and 'the sinking titanic' that characterized the beginning of the year, were replaced by more positive metaphors at the end of the year: "I am the eagle- I can fly! This year has given me wings- I feel confident to go and teach next year".

The excursion proved to be a powerful initiative in the pre-service education of teachers. In the South African context, with our racially divided history, it is of essence to prepare teachers who are able to mediate learning in settings characterized by cultural and linguistic diversity. However, it is needed that student teachers delve deep into themselves first, and identify (and work on) their own preconceived ideas and biases.

Case-based teaching provides student teachers the opportunity to learn from practice. Case-based teaching provides student teachers with a more nuanced understanding of the demands facing a teacher and assist them in their professional development. De Beer \& Gravett (2016) also argue that case-based teaching holds affordances for self-direction in learning and for deep approaches to learning.

In conclusion: research and teaching go hand in hand, and provided that there are good relationships between student teachers and teacher educators, these stakeholders could jointly engage in projects that would lead to a better understanding of the complexities of teaching and learning-for both teacher educators, and the student teachers. Such engaging approaches and pedagogies can go a long way in helping student teachers to think and act like teachers.

\section{References}

Centre for Development and Enterprise. 2011. Value in the classroom: The quantity and quality of South Africa's teachers. CDE In Depth Number 11. Johannesburg: CDE.

Chmielewski, J.G. and Stapleton, M.G. 2009., The undergraduate research experience: It's not for everyone, students and faculty alike. BIOS, 80(2), pp.53-58.

Darling-Hammond, L., 2006. Constructing 21st-century teacher education. Journal of teacher education, 57(3), pp.300-314.

De Beer, J. 2016., Re-imagining science education in South Africa: The affordances of indigenous knowledge for self-directed learning in the school curriculum. Journal for New Generation Sciences, 14(3), pp.34-53.

De Beer, J. \& Gravett, S., 2016. The affordances of case-based teaching for self-directed learning: a case study with first-year student teachers. In: E. Mentz and I. Oosthuizen (eds), Self-directed learning research, pp. $35-71$. Cape Town: AOSIS.

De Beer, J. and Henning, E., 2011. Retreating to a Vygotskian stage where pre-service teachers play out social "dramatical collisions". Acta Academica, 43(4), pp.1- 26. 
De Beer, J., Petersen, N. and Dunbar-Krige, H., 2012. An exploration of the value of an educational excursion for preservice teachers. Journal of Curriculum Studies, 44(1), pp.89-110.

Engeström, Y., 1987. Learning by expanding: An activity-theoretical approach to developmental research. Helsinki: Orienta-Konsultitl.

Feiman-Nemser, S. and Floden, R., 1986. The cultures of teaching. In: M. Wittrock (Ed), Handbook of research on teaching (pp 505 -526). New York: MacMillan.

Gravett, S., De Beer, J., Odendaal-Kroon, R. and Merseth, K.K., 2016. The affordances of case-based teaching for the professional learning of student-teachers. Journal of Curriculum Studies, DOI: 10.1080/00220272.2016.1149224.

Huizinga, J., 1955. Homo Ludens: A Study of the Play-element in Cult. Beacon Press.Intrator, S. \&

Kunzman, R., 2009. Grounded: Practicing what we preach. Journal of Teacher Education, 60(1), pp.512 -519 .

Kessels, P. and Korthagen, F., 1996. The relationship between theory and practice: Back to the classics. Educational Researcher, 25(1), pp.17- 22.

Kinsella, E.A. and Pitman, A., 2012. Phronesis as professional knowledge: Practical wisdom in the professions, professional practice and education. A diversity of voices.

Korthagen, F.A., 2011. Making teacher education relevant for practice: The pedagogy of realistic teacher education. Orbis scolae, 5(1), pp.31-50.

Kosnik, C., Beck, C., Freese, A.R. and Samaras, A.P. eds., 2006. Making a difference in teacher education through self-study: Studies of personal, professional and program renewal (Vol. 2). Springer Science \& Business Media.

Lortie, D., 1975. Schoolteacher. Chicago: University of Chicago Press.

Merseth, K., 1996. Cases and case methods in teacher education. In: J. Sikula (Ed), Handbook of research on teacher education. New York: Simon \& Schuster.

Saldana, J., 2009. The coding manual for qualitative researchers. London: Sage.

Sawada, D., Piburn, M.D. and Judson, E., 2002. Measuring reform practices in science and mathematics classrooms: The Reformed Teaching Observation Protocol. School Science and Mathematics, 102(3), pp.245 - 253.

Schön, D.A., 1987. Educating the reflective practitioner. San Francisco: Jossey Bass.

Shulman, J.H., 2002. Happy accidents: cases as opportunities for teacher learning. Paper presented at the annual meeting of the American Educational Research Association, New Orleans, LA.

Shulman, L.S., 2004. The wisdom of practice. Essays on teaching, learning and learning to teach. San Francisco: Jossey-Bass.

Sitte, W. and Wohlschlagl, H., 2001. Didactic plays. Contributions for the teaching of geography and industrial studies instruction (Beitrage zur Didaktik des Geographie und Witschaftskunde Unterricht.) Vienna: Institute for Geography and Regional Studies. 
Van Lier, L., 2004. The ecology of language learning. Accessed on-line: http://uccllt.ucdavis.edu/events/ULCCTPP/leo.php, on 22 June 2014.

Vygotsky, L.S., 1978. Mind in society. London: Harvard University Press.

Warford, M.K., 2011. The zone of proximal teacher development. Teaching and Teacher Education, $27(1)$, pp.252 - 258. 